\title{
PENGEMBANGAN MEDIA PEMBELAJARAN BERBASIS WEBSITE WIX PADA MATA PELAJARAN PRODUKSI PENGOLAHAN HASIL NABATI DI SMKN 2 CILAKU CIANJUR
}

\author{
Development of WIX Website Based Learning Media in Vegetable Product Processing \\ Production Lessons at SMKN 2 Cilaku Cianjur
}

\author{
Restia Rahmawati*, Yanni Achdiani, Mustika Nuramalia Handayani \\ Program Studi Pendidikan Teknologi Agroindustri, \\ Fakultas Pendidikan Teknologi dan Kejuruan, Universitas Pendidikan Indonesia, \\ *restiarahmawati@upi.edu
}

\begin{abstract}
ABSTRAK
Kegiatan pembelajaran pada masa Pandemi Covid-19 umunya dilaksanakan secara daring, demikian juga dengan kondisi di SMKN 2 Cilaku Cianjur, hal ini dilakukan sebagai salah satu upaya untuk mencegah penyebaran Covid-19. Media pembelajaran yang digunakan berupa Google Classroom dan grup Whatsapp khususnya pada mata pelajaran Produksi Pengolahan Hasil Nabati. Media pembelajaran berbasis website WIX dapat menjadi salah satu inovasi dan menjadi pilihan untuk digunakan dalam proses belajar mengajar secara daring. Tujuan dari penelitian ini,yaitu: 1) Mengetahui kelayakan media pembelajaran berbasis website WIX pada mata pelajaran Produksi Pengolahan Hasil Nabati, 2) Mengetahui hasil belajar siswa setelah menggunakan media pembelajaran berbasis website WIX. Pengembangan media pembelajaran berbasis website WIX ini menggunakan metode Waterfall dengan tahapan Analisis Kebutuhan, Desain Sistem, Implementasi, Integrasi \& Pengujian, Penerapan Sistem, dan Pemeliharaan. Website WIX diterapkan kepada siswa untuk mengetahui hasil belajar siswa dengan menggunakan desain Pre-eksperimental Design dengan bentuk One Group PretestPostest Design. Hasil dari penelitian menunjukan bahwa website WIX dinyatakan "sangat layak" oleh ahli media, ahli materi, ahli bahasa, dan dinyatakan layak oleh siswa. Hasil belajar siswa mengalami peningkatan setelah menggunakan website WIX berdasarkan nilai ketuntasan KKM siswa. Pada uji NGain didapatkan nilai rata-rata N-Gain sebesar 0,68 dengan kriteria "sedang", dan pada uji Wilcoxon didapatkan nilai Sig. $(0,000)<0,5$, sehingga penggunaan website WIX berpengaruh terhadap peningkatan hasil belajar siswa.
\end{abstract}

Kata kunci: Media pembelajaran, pengolahan hasil nabati, website WIX

\begin{abstract}
Learning activities during the Covid-19 pandemic, are generally carried out online, as well as conditions at SMKN 2 Cilaku Cianjur, this is done as an effort to prevent the spread of Covid-19. The learning media used are Google Classroom and WhatsApp groups, especially in the subject of Vegetable Product Processing Production. The development of learning media based on the WIX website can be one of the innovations and can be an option for use in the online teaching and learning process. The objectives of this study are: 1) Knowing the feasibility of WIX website-based learning media in the subject of Vegetable Product Processing Production, 2) Knowing student learning outcomes after using WIX website-based learning media. The development of this WIX website-based learning media uses the Waterfall method with the stages of Requirements Analysis, System Design, Implementation, Integration \& Testing, System Implementation, and Maintenance. The WIX website is applied to students to determine student learning outcomes by using Pre-experimental Design in the form of One Group Pretest-Postest Design. The results of the research show that the WIX website is declared "very feasible" by media experts, material experts, linguists' experts, and declared worthy by students. The student learning outcomes have increased after using the WIX website based on students' KKM completeness scores. In the $N$-Gain test, the average of $N$-Gain value is 0.68 with "medium" criteria, and in the Wilcoxon test the Sig value is obtained. $(0.000)<0.5$, so the use of the WIX website influences increasing student learning outcomes.
\end{abstract}

Keywords: Learning media, vegetable product processing, WIX website. 


\section{PENDAHULUAN}

Pendidikan merupakan salah satu sektor yang terkena dampak cukup tinggi di tengah kondisi Pandemi Covid-19 ini. Pemerintah, khususnya Menteri Pendidikan dan Kebudayaan, mengeluarkan Surat Edaran MENDIKBUD No.4 Tahun 2020 tentang Kebijakan Pelaksanaan Pendidikan dalam Masa Darurat Penyebaran Coronavirus Disease (Covid-19). Pada kondisi ini yang mengharuskan siswa untuk belajar secara mandiri di rumah karena proses pembelajaran pun dilakukan secara daring (dalam jaringan), demikian juga dengan kondisi di SMKN 2 Cilaku Cianjur, hal ini dilakukan sebagai salah satu upaya untuk mencegah penyebaran Covid-19 dan mengikuti aturan yang ditetapkan oleh pemerintah.

Media pembelajaran menjadi sarana utama untuk keberjalanan proses belajar mengajar terutama pada kondisi Pandemi saat ini, karena semakin dibutuhkan untuk mengatasi berbagai permasalahan, seperti keterbatasan tempat, waktu, dan fasilitas. Media pembelajaran merupakan suatu sarana yang memiliki sifat menyalurkan pesan dan dapat merangsang pikiran, perasaan dan kemampuan peserta didik sehingga mendorong terjadinya proses belajar (Kalatting, dkk., 2015). Penggunaan website dapat menjadi salah satu alternatif media pembelajaran yang dapat digunakan dalam kegiatan belajar mengajar. Website yang dapat digunakan sebagai media pembelajaran beragam, salah satu jenis yaitu website WIX.

Di SMK Negeri 2 Cilaku Cianjur khususnya pada mata pelajaran Produksi Pengolahan Hasil Nabati belum ada yang menggunakan website WIX sebagai media pembelajaran. Mata pelajaran Produksi Pengolahan Hasil Nabati merupakan mata pelajaran produktif pada SMK dengan kompetensi keahlian Agribisnis Pengolahan Hasil Pertanian. Media pembelajaran yang digunakan pada mata pelajaran tersebut hanya melalui Google Classroom dan aplikasi Whatsapp. Pengembangan website sebagai media pembelajaran ini dapat menjadi salah satu inovasi dan dapat menjadi pilihan untuk digunakan dalam proses belajar mengajar secara daring. Penggunaan website WIX sebagai media pembelajaran dapat memberikan pengalaman belajar yang baru kepada siswa dalam mempelajari materi Produksi Pengolahan Hasil Nabati. Diharapkan dengan belajar menggunakan website WIX ini dapat meningkatkan hasil belajar siswa khususnya secara kognitif. Tujuan dari penelitian ini yaitu untuk mengetahui kelayakan media pembelajaran berbasis website WIX, dan mengetahui hasil belajar siswa setelah menggunakan media pembelajaran berbasis website WIX pada mata Pelajaran Produksi Pengolahan Hasil Nabati di SMKN 2 Cilaku Cianjur.

\section{METODE}

Metode penelitian yang digunakan untuk pengembangan media pembelajaran berbasis website WIX yaitu metode Waterfall. Pada metode Waterfall terdiri dari 6 langkah, yaitu : (1) Resquirement analysis (analisis persyaratan), (2) System design (desain sistem), (3) Implementation (implementasi), (4) Integration \& testing (integrasi dan pengujian), (5) Deployment of system (penerapan sistem), (6) Maintenance (perawatan). Pada penelitian ini juga dilaksanakan penerapan media pembelajaran dengan menggunakan metode Pre-eksperimental Design dengan bentuk One Group Pretest-Postest Design. Berikut desain One Group Pretest-Postest Design yang digunakan pada penerapa website WIX:

\begin{tabular}{ccc}
\hline Pre test & Treatment & Post test \\
\hline 01 & $\mathrm{X}$ & $\mathrm{O} 2$ \\
\hline & Sumber: Azizah (2013) &
\end{tabular}

Keterangan:

- O1: Tes awal (pre test) dilaksanakan sebelum menggunakan media pembelajaran berbasis website WIX

- $\quad$ X: Perlakuan pembelajaran dengan menggunakan media pembelajaran berbasis website WIX

- O2: Tes awal (postest) dilaksanakan sebelum menggunakan media pembelajaran berbasis website WIX

Pada pengembangan media pembelajaran berbasis website WIX instrument yang digunakan yaitu instrument kelayakan ahli materi, keyakan ahli bahasa, kelayakan ahli media, dan kuisioner respon penilaian siswa. Pada penerapan website WIX, instrument yang digunakan yaitu instrument kelayakan soal, dan soal pretest-posttest. 
Partisipan yang terlibat pada pengembangan media pembelajaran website WIX yaitu validator ahli media, ahli materi, dan ahli bahasa yang merupakan guru di SMKN 2 Cilaku Cianjur, dan siswa kelas XII APHP sebanyak 77 orang. Sedangkan pada penerapan website WIX, sampel yang terlibat yaitu siswa kelas XI APHP sebanyak 68 orang. Teknik pengambilan sampling yang digunakan pada penerapan media pembelajaran yaitu menggunakan tektik sampel total, sehingga semua siswa kelas XI APHP diberi perlakuan yang sama.

Penilaian kelayakan yang dilakukan pada instrument ahli media, ahli materi, ahli bahasa, dan kuisioner respon penilaian siswa menggunakan Skala Likert, yaitu dikonversikan ke dalam skor skala 1-4 yang dapat dilihat pada Tabel 1.

Tabel 1. Kriteria Skor Skala Likert

\begin{tabular}{ll}
\hline Skor & Kriteria Nilai \\
\hline $\mathbf{1}$ & Sangat Tidak Setuju (STS) \\
\hline $\mathbf{2}$ & Tidak Setuju (TS) \\
\hline $\mathbf{3}$ & Setuju (S) \\
\hline $\mathbf{4}$ & Sangat Setuju (ST) \\
& Sumber: Sugiyono (2015)
\end{tabular}

Hasil kuisioner dan lembar validasi selanjutnya dianalisis. Metode yang digunakan yaitu deskriptif kuantitatif. Cara perhitungan pada metode ini yaitu dalam bentuk distribusi skor-skor dan persentase setiap instrument. Rumus yang digunakan pada analisis data ini sebagai berikut:

$$
\text { Presentasi }(100 \%)=\frac{\text { Jumlah skor }(\mathrm{X})}{\text { Skor maksimum }(\mathrm{Xi})} \times 100 \%
$$

Hasil dari perhitungan persentase pada setiap instrument selanjutnya dikonversikan untuk mengetahui hasil tingkat kelayakan website WIX. Tabel interpretasi kelayakan website WIX dapat dilihat pada Tabel 2.

Tabel 2. Interpretase Kelayakan Media Pembelajaran Berbasis Website WIX

\begin{tabular}{llll}
\hline Skor & Kriteria & Persentase & Konversi \\
\hline $\mathbf{1}$ & Sangat Tidak Setuju & $25,00 \%-43,75 \%$ & Sangat Tidak Layak \\
\hline $\mathbf{2}$ & Tidak Setuju & $43,76 \%-62,50 \%$ & Tidak Layak \\
\hline $\mathbf{3}$ & Setuju & $62,51 \%-81,25 \%$ & Layak \\
\hline $\mathbf{4}$ & Sangat Setuju & $81,26 \%-100 \%$ & Sangat Layak \\
\hline
\end{tabular}

Sumber: Akbar (2013)

Pada analisis data lembar validasi soal digunakan untuk mengetahui kelayakan soal pre-test dan post-test sebelum diberikan kepada siswa. Pada lembar validasi soal ini juga disusun dengan menggunakan skala penilaian skor 1-4, yang dapat dilihat pad Tabel 3.

Tabel 3.Skala Penilaian validasi Soal

\begin{tabular}{ll}
\hline Skor & Keterangan \\
\hline $\mathbf{1}$ & Sangat Kurang Baik \\
\hline $\mathbf{2}$ & Kurang Baik \\
\hline $\mathbf{3}$ & Baik \\
\hline $\mathbf{4}$ & Sangat Baik \\
\hline
\end{tabular}

Sumber: Sugiyono (2017)

Hasil dari validasi soal selanjutnya dianalisis dengan menggunakan rumus persentase dan dilakukan penafsiran data yang merujuk pada kriteria kualifikasi yang mengacu pada Akbar (2013) yang dapat dilihat pada Tabel 4.

$$
\text { Presentasi }(100 \%)=\frac{\text { Jumlah skor }(\mathrm{X})}{\text { Skor maksimum }(\mathrm{Xi})} \times 100 \%
$$


Tabel 4. Interpretasi Hasil Penilaian Kelayakan Soal Pre Test-Post Test

\begin{tabular}{llll}
\hline Skor & Kriteria & Persentase & Konversi \\
\hline $\mathbf{1}$ & Sangat Kurang Baik & $25,00 \%-43,75 \%$ & Sangat Tidak Layak \\
\hline $\mathbf{2}$ & Kurang Baik & $43,76 \%-62,50 \%$ & Tidak Layak \\
\hline $\mathbf{3}$ & Baik & $62,51 \%-81,25 \%$ & Layak \\
\hline $\mathbf{4}$ & Sangat Baik & $81,26 \%-100 \%$ & Sangat Layak \\
\hline & & Sumber : Akbar (2013) &
\end{tabular}

Pada penilaian hasil belajar siswa akan menghasilkan data nilai siswa yang terdiri dari nilai pretest dan post-test. Nilai tersebut selanjutnya dianalisis untuk mengetahui ketuntasan siswa terhadap materi yang dipelajari pada website WIX yaitu sayur segar untuk satuan produksi. Pada mata pelajaran Produksi Pengolahan Hasil Nabati untuk kelas XI di SMKN 2 Cilaku Cianjur pada tahun 2021 memiliki Kriteria Ketuntasan Minimal (KKM) yaitu sebesar 75. Selanjutnya dilakukan uji N-Gain untuk mengetahui mengetahui ada atau tidaknya peningkatan nilai hasil belajar siswa pada pre-test dan posttest. Rumus yang digunakan pada uji ini sebagai berikut:

$$
N \text {-Gain }=\frac{\text { skor post test-skor pre test }}{\text { skor maksimum-skor pre test }}
$$

Hasil dari pengolahan nilai $\mathrm{N}$-Gain selanjutnya diintepretasikan ke dalam skala kriteria $\mathrm{N}$-Gain. Uji $N$ Gain dilakukan menggunakan IBM SPSS 25 . Terdapat skala nilai yang digunakan pada $N$-Gain ini, yaitu dapat dilihat pada Tabel 5 .

Tabel 5. Skala Kriteria N-Gain

\begin{tabular}{ll}
\hline Skor & Kriteria \\
\hline $\mathbf{N}$-Gain $\geq 0,70$ & Tinggi \\
\hline $\mathbf{0 , 3 0} \leq \mathbf{N}$-Gain $<\mathbf{0 , 7 0}$ & Sedang \\
\hline $\mathbf{N}$-Gain $<\mathbf{0 , 3 0}$ & Rendah
\end{tabular}

Sumber : Solehudin (2018)

Pada penilaian hasil belajar siswa juga dilakukan uji normalitas, dan uji homogenitas. Jika data hasil belajar siswa (pre-test-post-test) menunjukan data terdistribusi normal dan homogen, maka dilakukan uji lanjut paired sample T-Test, sedangkan jika data tidak terdistribus normal dan tidak homogen maka dilakukan dengan uji lanjut Wilcoxon. Uji-uji tersebut dilakukan dengan menggunakan IBM SPSS 25. Adapun kriteria pada uji Wilcoxon yaitu:

- Jika nilai Sig $<0,05$ maka Ho ditolak dah H1 diterima

- Jika nilai Sig > 0,05 maka Ho diterima dan H1 ditolak

Keterangan:

- Ho: Tidak terdapat perbedaan rata-rata diantara kedua data (Pre-Test \& Post Test)

- H1: Terdapat perbedaan rata-rata diantara kedua data (Pre-Test \& Post Test)

\section{HASIL DAN PEMBAHASAN}

\section{Pengembangan Media Pembelajaran Berbasis Website WIX}

Pada pengembangan media pembelajaran berbasis website menggunakan model pengembangan Waterfall dengan tahapan meliputi Requirement Analysis, System Design, Implementation, Integration \& Testing, Deployment of System, dan Maintenance. Metode Waterfall menekankan pada sebuah keterurutan dalam program pengembangan perangkat lunak dan merupakan metode yang tepat untuk membangun sebuah perangkat lunak yang tidak terlalu besar (Yanti, dkk., 2018). Media pembelajaran berbasis website WIX untuk mata pelajaran Produksi Pengolahan Hasil Nabati yang telah selesai dikembangkan oleh peneliti dapat diakses dengan menggunakan link berikut ini: https://restiarahmawati20.wixsite.com/mediapembelajaran. Website tersebut dapat diakses dengan menggunakan perangkat seperti handphone, laptop atau komputer yang terkoneksi dengan internet yang di dalamnya terdapat perangkat lunak dengan berbagai jenis browser seperti Google, Google Chrome, Mozilla Firefox, Opera, dan lain-lain dengan cara memasukkan link pada mesin pencarian. Hasil dari pengembangan website WIX dapat dilihat pada gambar-gambar berikut ini: 


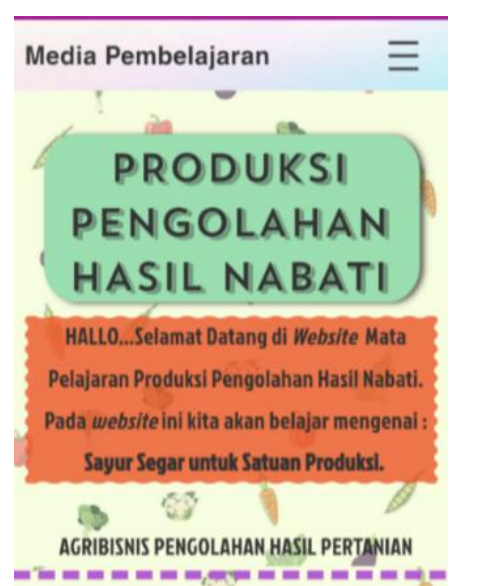

Gambar 1. Tampilan

Halaman Awal website WIX (Mode Handphone)

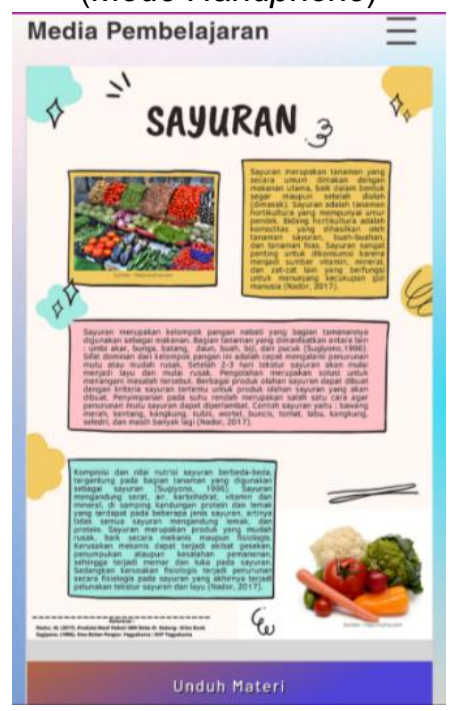

Gambar 4. Tampilan Salah Satu Isi Materi (Mode Handphone)

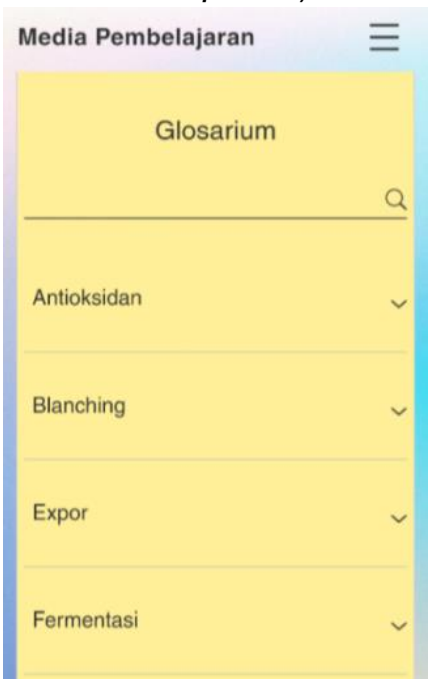

Gambar 7. Tampilan Glosarium (Mode Handphone)

\section{Validasi Ahli Media}

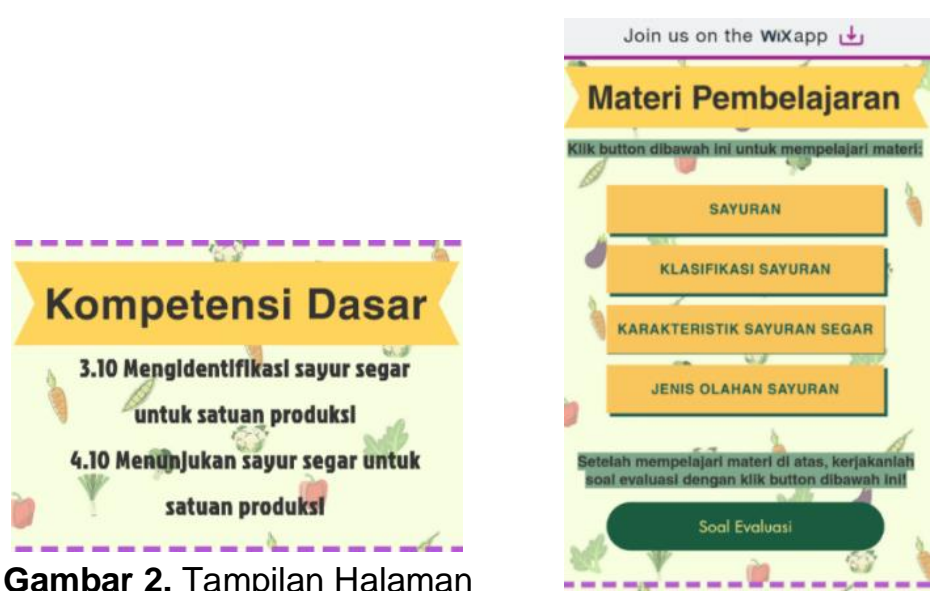

Kompetensi Dasar (Mode Handphone)

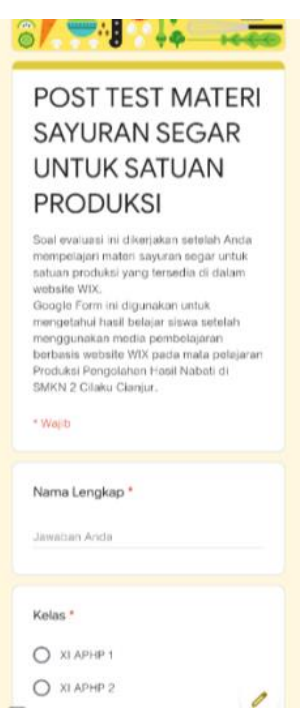

Gambar 5. Tampilan Google Form Soal Evaluasi (Mode Handphone)

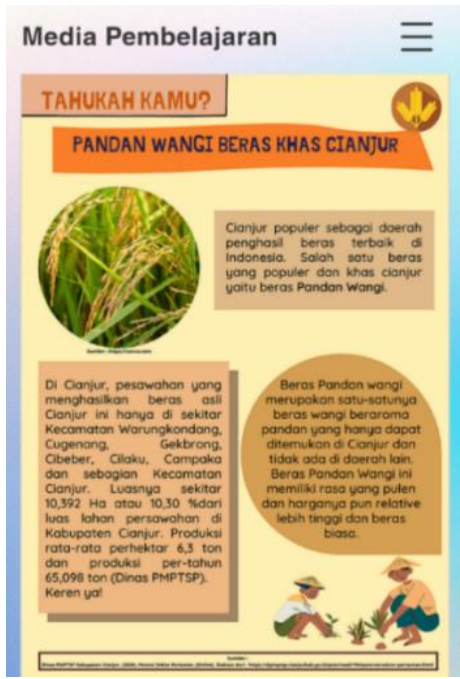

Gambar 8. Tampilan Salah Satu Isi "Tahukah kamu?" (Mode Handphone)
Gambar 3. Tampilan Halaman Materi Pembelajaran (Mode Handphone)

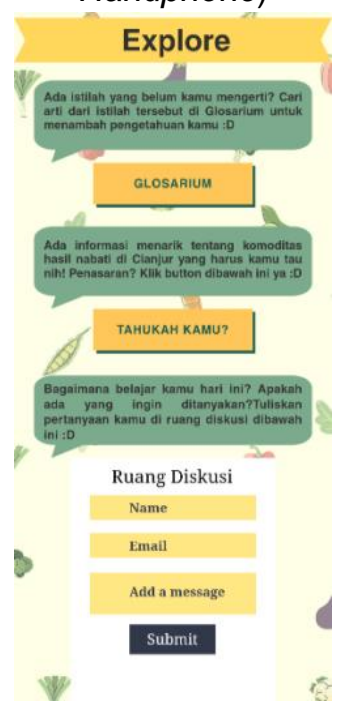

Gambar 6. Tampilan Halaman Explore (Mode Handphone)

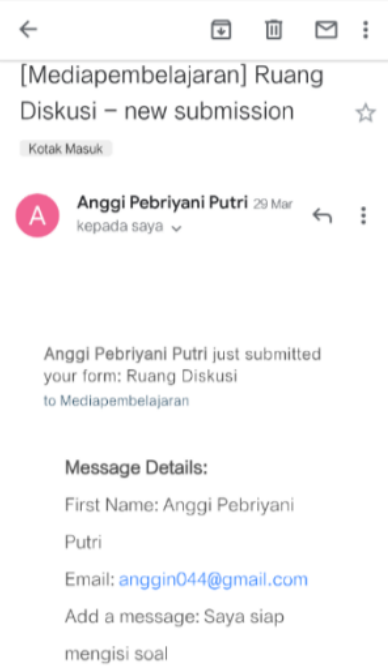

Gambar 9. Pesan Pada Ruang Diskusi yang Ditulis oleh Siswa (e-mail) 
Validasi kepada ahli media merupakan tahapan untuk melakukan integrasi dan pengujian terhadap media pembelajaran website WIX yang dikembangkan apakah sudah layak untuk digunakan dilihat dari beberapa aspek yang berkaitan dengan media yang dikembangkan. Aspek yang dinilai oleh ahli media diantaranya aspek usability, functionality, dan komunikasi visual. Aspek yang dinilai tersebut merupakan modifikasi dari Lukitaningrum (2016). Hasil dari validasi ahli media dapat dilihat pada Gambar 10.

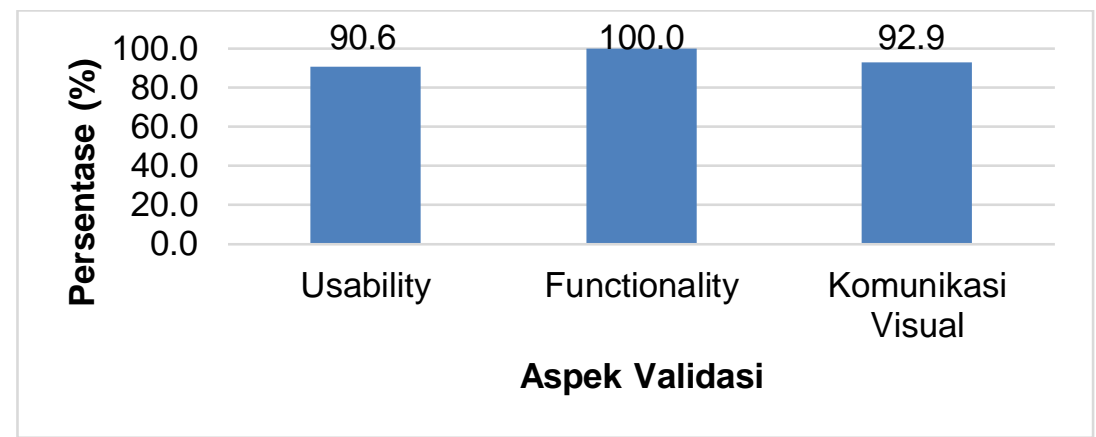

Gambar 10. Validasi Ahli Media

Berdasarkan hasil penilaian oleh ahli media, media pembelajaran website WIX yang dikembangkan mendapatkan nilai rata-rata 94,5\%. Dengan demikian, kriteria untuk website WIX yang dikembangkan menurut ahli media yaitu "sangat setuju" dan tingkat kelayakan "sangat layak". Tidak terdapat revisi atau perbaikan dari ahli media terhadap website WIX. Adapun komentar dari ahli media yaitu "Media yang disajikan sangat menarik dan informatif, sehingga diharapkan bisa mempermudah dan menarik minat siswa/siswi.". Menurut Wahid (2018) dengan adanya media pembelajaran dapat memperbesar minat dan perhatian siswa untuk belajar. Ciri-ciri adanya minat siswa terhadap materi pelajaran antara lain : siswa merasa senang, siswa tertarik terhadap objek yang diamati, adanya perhatian siswa dalam pembelajaraan, dan siswa terlibat dalam proses pembelajaran (Paseleng dan Arfiyani, 2015). Kesimpulan yang didapatkan dari validasi ahli media yaitu media pembelajaran berbasis website WIX dinyatakan layak dan dapat digunakan tanpa perbaikan.

\section{Validasi Ahli Materi}

Validasi kepada ahli materi merupakan tahapan untuk melakukan integrasi dan pengujian terhadap media pembelajaran website WIX yang dikembangkan apakah sudah layak untuk digunakan dilihat dari beberapa aspek yang berkaitan dengan materi yang terdapat di dalam media yang dikembangkan. Aspek yang dinilai oleh ahli materi diantaranya aspek kesesuaian materi dengan SK dan KD, keakuratan materi, dan mendorong keingintahuan. Aspek yang dinilai tersebut merupakan modifikasi dari Badan Standar Nasional Pendidikan (BNSP) (2008). Hasil dari validasi ahli materi dapat dilihat pada Gambar 11.

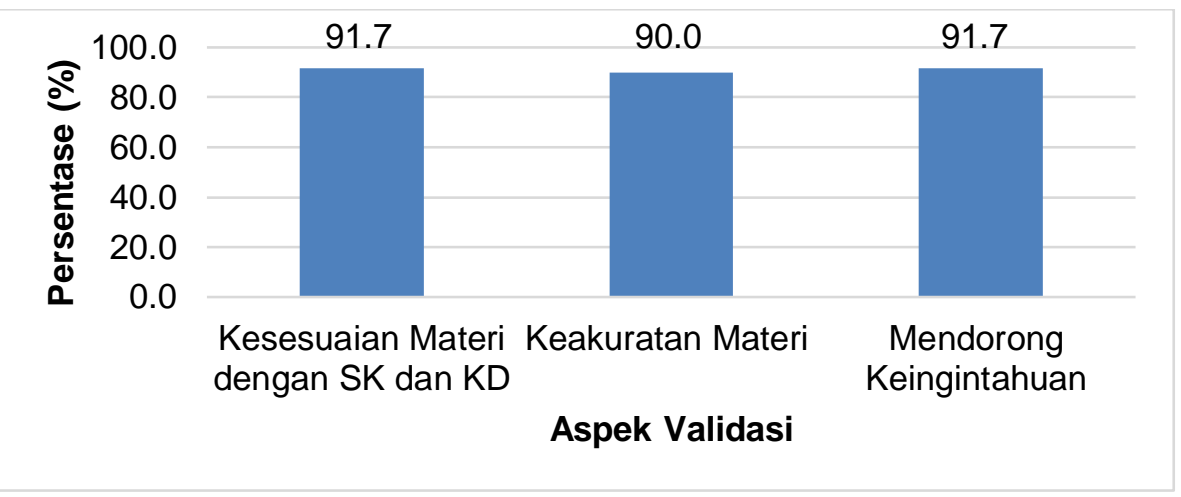

Gambar 11. Validasi Ahli Materi

Berdasarkan hasil penilaian oleh ahli materi, media pembelajaran website WIX yang dikembangkan mendapatkan nilai rata-rata $91,1 \%$, dengan kriteria "sangat setuju" dan tingkat kelayakan "sangat layak". Tidak terdapat revisi atau perbaikan dari ahli media terhadap website WIX. Adapun komentar dari ahli materi yaitu "Materi lengkap dan luas, pemberian pelengkap seperti gambar, diagram, dan ilustrasi sehingga meningkatkan rasa ingin tahu.". Media pembelajaran dapat membantu guru dalam menciptakan suasana belajar menjadi lebih hidup, tidak monoton, dan tidak membosankan (Wahid, 2018). Terlebih disaat masa Pendemi saat ini media pembelajaran berperan penting dalam 
proses belajar jarak jauh. Kesimpulan yang didapatkan dari penilaian ahli materi yaitu media pembelajaran berbasis website WIX dinyatakan layak dan dapat digunakan tanpa perbaikan.

\section{Validasi Ahli Bahasa}

Validasi kepada ahli bahasa bertujuan untuk mengetahui kelayakan untuk digunakan dilihat dari beberapa aspek yang berkaitan dengan kebahasaan yang digunakan di dalam media yang dikembangkan. Aspek yang dinilai oleh ahli bahasa diantaranya aspek kelugasan, komunikatif, dialogis dan interaktif, kesesuaian dengan perkembangan pendidikan, kesesuaian dengan kaidah bahasa, dan penggunaan istilah, simbol, atau ikon. Aspek yang dinilai tersebut merupakan modifikasi dari Badan Standar Nasional Pendidikan (BNSP) (2008). Hasil dari validasi ahli bahasa dapat dilihat pada Gambar 12.

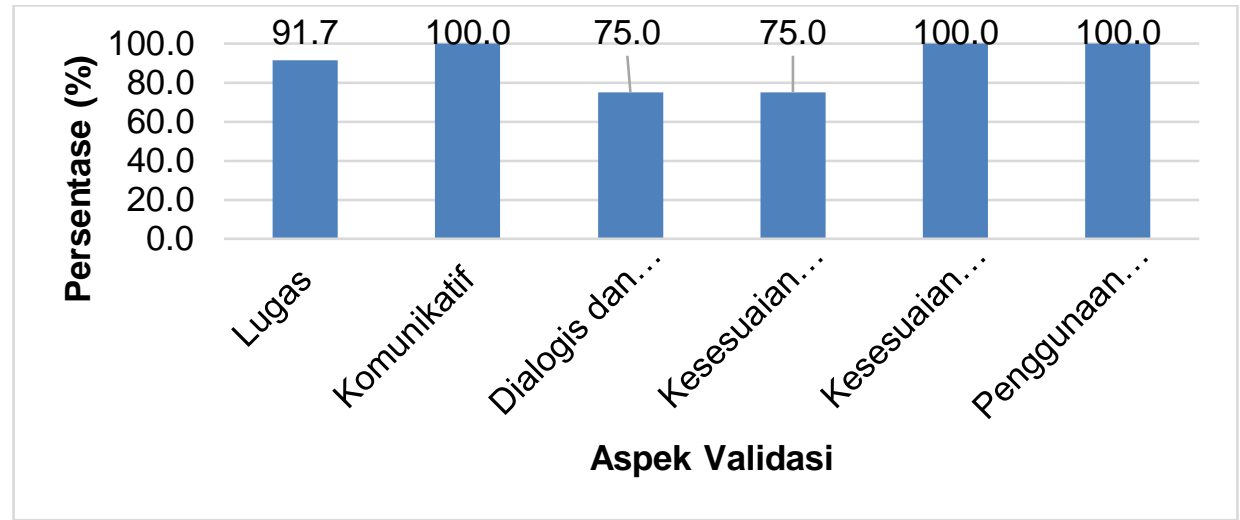

Gambar 12. Validasi Ahli Bahasa

Berdasarkan hasil penilaian oleh ahli bahasa, media pembelajaran website WIX yang dikembangkan mendapatkan nilai rata-rata 90,3\%, dengan kriteria "sangat setuju" dan tingkat kelayakan "sangat layak". Hasil penilaian tersebut sudah melebihi 50\%. Menurut Arikunto (2006) produk dapat dikategorikan sudah baik apabila kriteria penilaian sudah mencapai 50\%. Tidak terdapat revisi atau perbaikan dari ahli bahasa terhadap website WIX. Kesimpulan yang didapatkan dari penilaian ahli bahasa yaitu media pembelajaran berbasis website WIX dinyatakan layak dan dapat digunakan tanpa perbaikan. Menurut Anggraeni \& Kustijono (2013) penggunaan kebakuan dan keefektifan kalimat harus diperhatikan agar bahasa yang digunakan dalam media pembelajaran dapat lebih mudah dipahami dan dimengerti oleh siswa.

\section{Pengujian oleh Siswa kelas XII AHP di SMKN 2 Cilaku Cianjur}

Pengujian oleh siswa ini dilakukan secara daring, yaitu dengan menggunakan Google Form. Kuisioner yang telah dibuat dalam bentuk Google Form disebarkan kepada siswa melalui grup Whatsapp yang di dalamnya terdapat siswa kelas XII APHP. Pada pengujian oleh siswa ini terdapat beberapa aspek yang menjadi penilaian, diantaranya: aspek kegunaan website, pemahaman materi, kualitas website, tampilan website, dan kepuasan penggunaan website. Aspek penialian tersebut merupakan modifikasi dari Sunwinarti dan Suwito (2016) dan Lukitaningrum (2016). Terdapat 52 orang siswa yang memberikan respon penilaian terhadap website WIX. Hasil dari analisis perhitungan respon penilaian siswa selanjutnya direkapitulasi sehingga menghasilkan nilai rata-rata dari setiap aspeknya. Adapun hasil respon penilaian siswa kelas XII dari setiap aspek dapat dilihat pada Gambar 13.

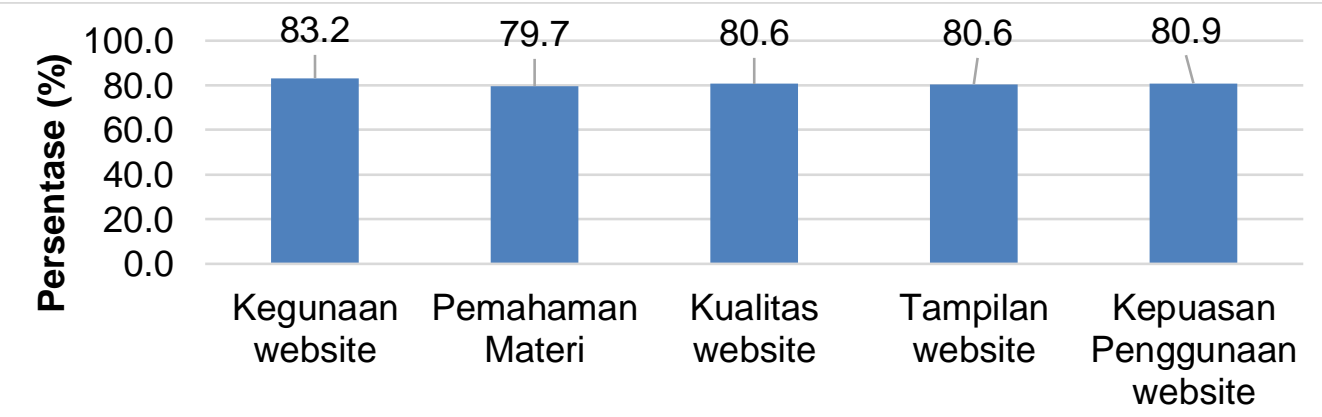

Aspek Penilaian 
Gambar 13. Respon Penilaian Siswa Kelas XII APHP

Berdasarkan hasil respon penilaian siswa, media pembelajaran website WIX yang dikembangkan mendapatkan nilai rata-rata $81 \%$, dengan kriteria "setuju" dan tingkat kelayakan "layak". Menurut Nisa \& Agung (2014) untuk mendapatkan hasil respon penilaian siswa dalam pengembangan sebuah media pembelajaran, lembar angket penilaian siswa diberikan kepada siswa yang sudah mendapatkan pengetahuan dan materi pembelajaran yang terdapat di dalam media pembelajaran tersebut.

\section{Penyebaran Sistem (Website WIX) pada Siswa Kelas XI APHP di SMKN 2 Cilaku Cianjur}

Tahap ini dilakukan setelah media pembelajaran website WIX dinyatakan layak oleh ahli media, ahli materi, ahli bahasa, dan juga telah disebarkan kepada siswa kelas XII APHP. Penyebaran sistem kepada siswa kelas XI APHP dilakukan secara daring yaitu melalui grup Whatsapp kelas. Terdapat 63 siswa yang memberikan respon penilaian terhadap website WIX. Hasil dari analisis perhitungan respon penilaian siswa kelas XI APHP dapat dilihat pada Gambar 14.

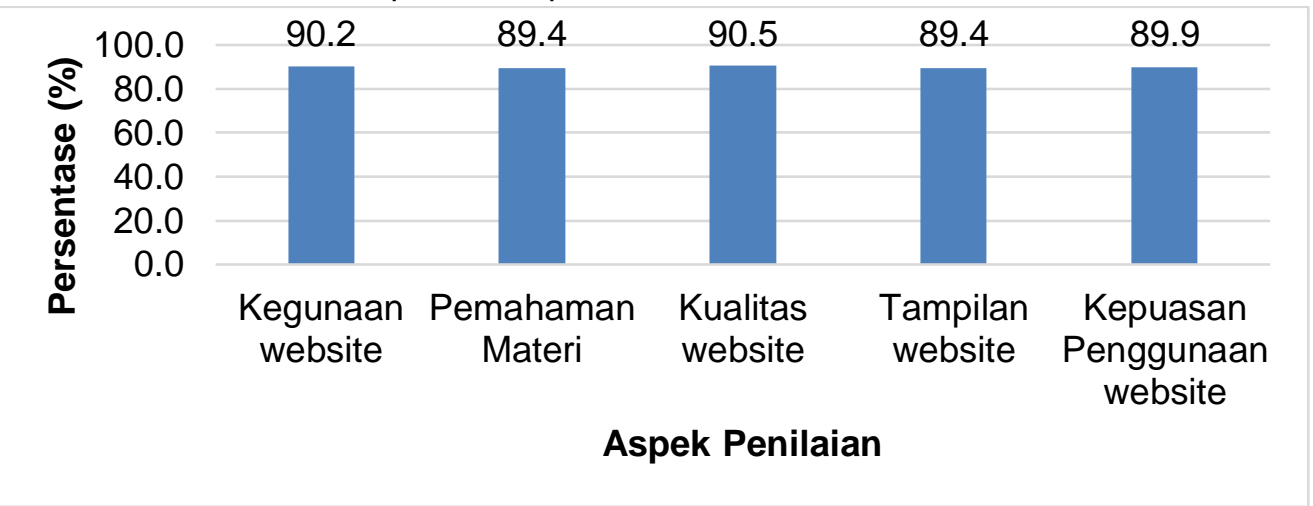

Gambat 14. Respon Penilaian Siswa Kelas XI APHP

Berdasarkan hasil respon penilaian siswa kelas XI APHP, media pembelajaran website WIX yang dikembangkan mendapatkan rata-rata persentase kelayakan $89,9 \%$, dengan kriteria "sangat setuju" dan tingkat kelayakan "sangat layak". Menurut Fauzan (2011) nilai sangat layak yang diberikan oleh siswa dapat diinterpretasikan bahwa tingkat ketertarikan dan antusias siswa terhadap media pembelajaran tergolong sangat tinggi, dan penggunaan media pembelajaran untuk siswa ini tergolong mudah digunakan, sehingga siswa tidak mengeluhkan kesulitan dalam menggunakannya.

\section{Penerapan Media Pembelajaran Berbasis Website WIX Terhadap Hasil Belajar Siswa}

\section{Penilaian Hasil Belajar Siswa}

Terdapat 67 siswa yang mengerjakan soal pre-test dan post-test. Rekapitulasi hasil belajar siswa sebelum diberikan website WIX (pre-test) dapat dilihat pada Gambar 15.

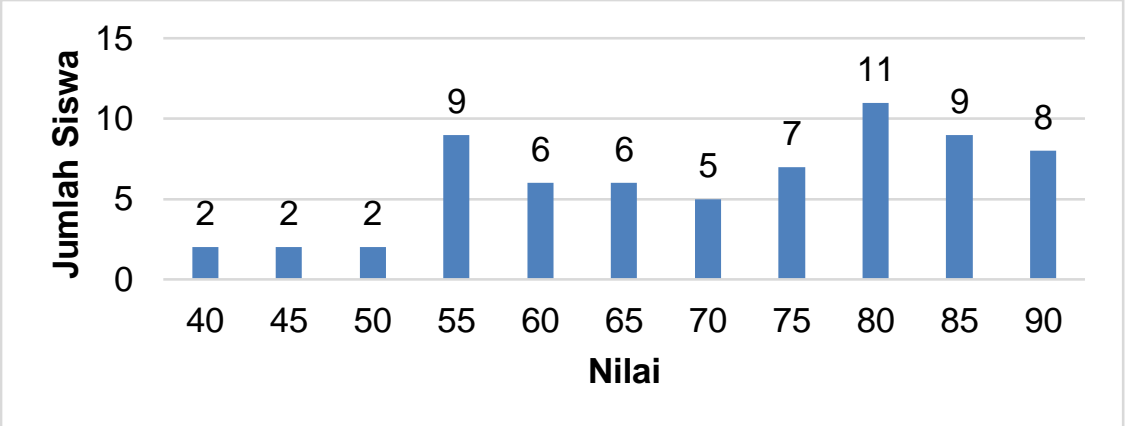

Gambar 15. Nilai Pre Test Siswa

Pada hasil diatas dilihat bahwa terdapat siswa yang mendapat nilai paling rendah yaitu 40 , dan nilai paling tinggi yaitu 90 . Berdasarkan hasil pre-test tersebut, nilai rata-rata secara keseluruhan yang diraih yaitu 71 .

Pada pelaksanaan post-test siswa, sama seperti pada saat pre-test terdapat 67 siswa yang mengerjakan soal. Hasil belajar siswa setelah diberikan media pembelajaran website WIX (post-test) dapat dilihat pada Gambar 16. 


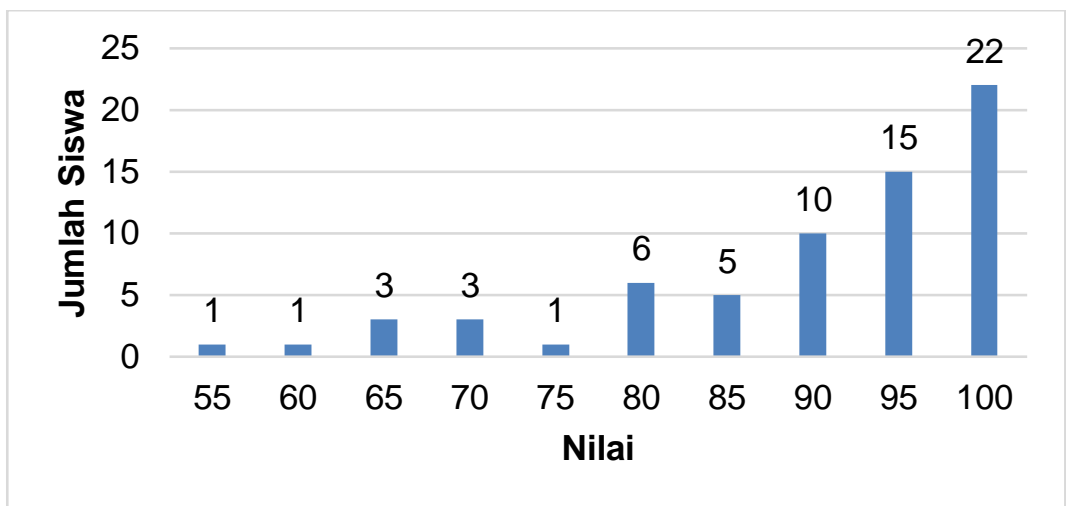

Gambar 16. Nilai Post Test Siswa

Berdasarkan hasil tersebut nilai paling rendah yang didapatkan oleh siswa yaitu 55 dan nilai paling tinggi yaitu 100. Didapat nilai rata-rata secara keseluruhan yang diraih siswa pada post-test ini yaitu 90.

Dari data nilai tersebut selanjutnya dilakukan analisis ketuntasan belajar siswa secara keseluruhan berdasarkan nilai KKM. Siswa yang tuntas yaitu jika mendapatkan nilai $\geq 75$, sedangkan siswa yang mendapatkan nilai $<75$ termasuk belum tuntas. Rekapitulasi ketuntasan nilai pre-test dan post-test siswa disajikan dalam diagram pie pada Tabel 6 .

Tabel 6. Hasil Ketuntasan Belajar Siswa

\begin{tabular}{|c|c|c|}
\hline Nilai & Tuntas & Belum Tuntas \\
\hline Pre Test & $52,24 \%$ & $47,76 \%$ \\
\hline Post Test & $88,06 \%$ & $11,94 \%$ \\
\hline
\end{tabular}

Berdasarkan tabel tersebut maka terjadi peningkatan hasil belajar siswa setelah menggunakan website WIX sebagai media pembelajaran pada mata pelajaran Produksi Pengolahan Hasil Nabati. Menurut Rini (2018) peningkatan nilai KKM menunjukan bahwa media pembelajaran yang digunakan sangat efektif untuk meningkatkan hasil belajar dalam kegiatan pembelajaran. Hal ini sejalan dengan pendapat menurut Putra \& Ekohariadi (2020) yang menyatakan bahwa pemanfaatan media pembelajaran berbasis website dapat meningkatkan hasil belajar dalam kegiatan belajar mengajar.

\section{Uji N-Gain}

Uji N-Gain dilakukan untuk mengetahui ada atau tidaknya peningkatan nilai hasil belajar siswa pada pre-test dan post-test. Hasil dari uji N-Gain terhadap hasil belajar siswa dapat dilihat pada Gambar 17.

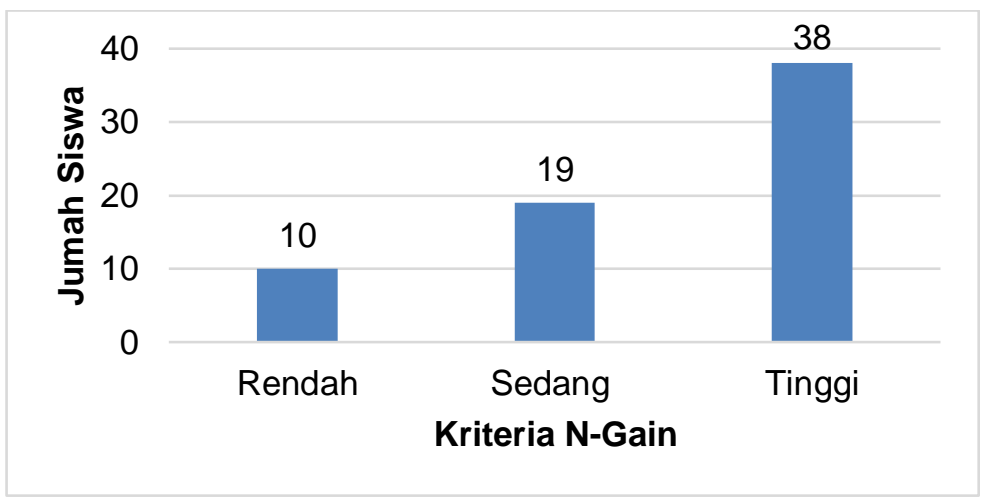

Gambar 17. Hasil Uji N-Gain

Dari hasil uji N-Gain tersebut didapatkan nilai rata-rata $\mathrm{N}$-Gain untuk media pembelajaran website WIX yaitu sebesar 0,68 dengan kriteria "sedang". Dengan demikian penggunaan media pembelajaran website WIX berpengaruh terhadap peningkatan hasil belajar siswa. Menurut Adriyani, dkk (2014) rata-rata nilai N-Gain menunjukkan besar peningkatan hasil belajar sebelum dan sesudah pembelajaran.

\section{Uji Wilcoxon}

Dari hasil uji normalitas dan uji homogenitas, data hasil belajar siswa tidak terdistribusi normal dan tidak homogen, maka dilakukan uji lanjutan yaitu dengan menggunakan uji Wilcoxon yang 
merupakan uji statistik nonparametrik yang dapat digunakan jika terdapat data yang tidak berdistribusi normal. Setelah dilakukan uji Wilcoxon, didapatkan hasil yang dapat dilihat pada Tabel 7.

Tabel 7. Hasil Uji Wilcoxon

\begin{tabular}{ll}
\hline \multicolumn{2}{l}{ Test Statistics $^{\mathbf{a}}$} \\
\hline & Post-Test-Pre-Test \\
\hline $\mathbf{Z}$ & $-6.819^{\mathrm{b}}$ \\
\hline Asymp. Sig. (2-tailed) & 0,000 \\
\hline a. Wilcoxon Signed Ranks Test
\end{tabular}

Berdasarkan hasil uji Wilcoxon tersebut didapatkan nilai Sig. $(0,000)<0,05$. Dengan demikian terdapat perbedaan rata-rata diantara kedua data (pre-test \& post-test). Hal ini menunjukan bahwa perlakuan dengan menggunakan media pembelajaran website WIX secara signifikan berpengaruh terhadap peningkatan hasil belajar siswa pada materi sayur segar untuk satuan produksi pada mata pelajaran Produksi Pengolahan Hasil Nabati. Menurut Afifah \& Hartatik (2019) jika hasil uji Wilcoxon menunjukkan nilai Asymp. Sig 0,000 0,05 maka dapat dinyakatan Ho ditolak, sehingga terdapat perbedaan antara hasil belajar siswa sebelum dan sesudah diterapkan media pembelajaran website WIX. Hal tersebut menunjukkan adanya pengaruh website WIX terhadap hasil belajar siswa.

\section{KESIMPULAN}

1. Penilaian media pembelajaran berbasis website WIX pada mata pelajaran Produksi Pengolahan Hasil Nabati yaitu dinyatakan sangat layak oleh ahli media, ahli materi, dan ahli bahasa. Website WIX juga dinyatakan layak oleh siswa kelas XII APHP dan dinyatakan sangat layak oleh siswa kelas XI APHP di SMKN 2 Cilaku Cianjur.

2. Terdapat peningkatan hasil belajar siswa setelah menggunakan media pembelajaran berbasis website WIX pada mata pelajaran Produksi Pengolahan Hasil Nabati berdasarkan ketuntasan hasil belajar yang mengacu pada nilai KKM mata pelajaran Produksi Pengolahan Hasil Nabati, yaitu siswa yang mendapatkan nilai tuntas diatas KKM pada hasil pre-test sebanyak 35 siswa, dan pada hasil post-test siswa yang mendapat nilai tuntas diatas KKM sebanyak 59 siswa. Pada uji N-Gain didapatkan nilai rata-rata N-Gain sebesar 0,68 dengan kriteria "sedang". Pada uji Wilcoxon didapatkan nilai Sig. $(0,000)<0,5$, sehingga penggunaan media pembelajaran berbasis website WIX berpengaruh terhadap peningkatan hasil belajar siswa pada mata pelajaran Produksi Pengolahan Hasil Nabati di SMKN 2 Cilaku Cianjur.

\section{DAFTAR PUSTAKA}

Afifah, N., \& Hartatik, S. (2019). Pengaruh Media Permainan Ular Tangga terhadap Motivasi Belajar pada Pelajaran Matematika Kelas II SD Kemala Bhayangkari 1 Surabaya. MUST: Journal of Mathematics Education, Science and Technology, 4(2), 209-216.

Akbar. (2013). Instrumen Perangkat Pembelajaran. Bandung: PT. Remaja Rosdakarya.

Andriyani, F., Jalmo, T., \& Yolida, B. (2014). Pengaruh Penggunaan Bahan Ajar Leaflet Terhadap Hasil Belajar Siswa. Jurnal Bioterdidik Wahana Ekspresi IImiah, 2(3), 1-11.

Anggraeni, R.D. \& Kustijono, R. (2013). Pengembangan Media Animasi Fisika Pada Materi Cahaya dengan Aplikasi Flash Berbasis Android. Jurnal Penelitian Fisika dan Aplikasinya, 3(1),1-18.

Arikunto. (2006). Prosedur Penelitian Suatu Pendekatan Praktek. Jakarta: PT. Rineka Cipta.

Azizah, T. (2013). Penggunaan Software Proteus Sebagai Media Pembelajaran untuk Meningkatkan Penguasaan Materi Pemrograman Mikrokontroler. (Skripsi). Universitas Pendidikan Indonesia, Bandung.

Fauzan, A. (2011). Analisis Kelayakan Media Pembelajaran Perakitan Komputer untuk Siswa Sekolah Menengah Kejuruan. (Skripsi). Univeristas Negeri Yogyakarta, Yogyakarta.

Kalatting, S., Serevina, V., \& Astra I.M. (2015). Pengembangan Media Pembelajran Fisika Berbasis Web Menggunakan Pendekatan Guided Discovery Learning. Jurnal Penelitian \& Pengembangan Pendidikan Fisika, 1(1), 1-8.

Lukitaningrum, H. (2016). Pengembangan Media Pembelajaran Berbasis Web Pada Materi Basis Data di Sekolah Menengah Kejuruan Kelas XI. (Skripsi). Universitas Negeri Yogyakarta, Yogyakarta.

Nisa, C. \& Agung, Y.A. (2014). Pengembangan Media Pembelajaran Berbasis ICT menggunakan Multisim10 Simulations Pada Mata Pelajaran Teknik Elektronika Dasar di SMK Negeri 7 
Surabaya. Jurnal Pendidikan Teknik Elektro, 3(2), 311-317.

Paseleng, M. C., \& Arfiyani, R. (2015). Pengimplementasian Media Pembelajaran Berbasis Multimedia Interaktif pada Mata Pelajaran Matematika di Sekolah Dasar. Scholaria: Jurnal Pendidikan Dan Kebudayaan, 5(2), 131-149.

Putra, F. N. B., \& Ekohariadi, E. (2020). Studi Literatur Pengaruh Media Pembelajaran Berbasis Website Terhadap Hasil Pembelajaran Administrasi Sistem Jaringan. IT-Edu: Jurnal Information Technology and Education, 5(2), 592-596.

Rini, A. (2018). Analisis Hasil Pemanfaatan Media Pembelajaran Interaktif Aljabar Logika Dengan User Acceptance Test (UAT). Smatika Jurnal, 8(2), 67-73.

Solihudin, T. (2018). Pengembangan E-Modul Berbasis Web Untuk Meningkatkan Pencapaian Kompetensi Pengetahuan Fisika Pada Materi Listrik Statis dan Dinamis SMK. Jurnal Wahana Pendidikan Fisika, 3(2), 51-56.

Sugiyono. (2015). Metode Penelitian Kombinasi (Mix Methods). Bandung: Alfabeta.

Sugiyono. (2017). Metode Penelitian Kuantitatif, Kualitatif dan R\&D. Bandung: Alfabeta.

Sunwinarti \& Suwito, D. (2016) Pengembangan Media Pembelajaran Berbasis Web untuk Meningkatkan Hasil Belajar Dasar-Dasar Mesin Kelas X di SMK Negeri 3 Buduran Sidoarjo. JPTM ,4(3),21-27.

Wahid, A. (2018). Pentingnya Media Pembelajaran dalam Meningkatkan Prestasi Belajar. Istiqra: Jurnal Pendidikan dan Pemikiran Islam, 5(2), 1-11.

Yanti, D., Purbowati, M.D., \& Mulyono, T. (2018). Teknologi Penjualan Berbasis Web (E-Commerce) Menggunakan WIX di CV. Maga Mas. Jurnal Teknologi dan Terapan Bisnis, 1(1), 27-33. 